\title{
RPTRA AS PUBLIC COMMUNICATION MEDIUM FOR THE GOVERNMENT OF DKI JAKARTA IN INTECHTING WITH CITIZENS
}

\author{
Rialdo Rezeky Manogari L. TORUAN* and Muhammad SAIFULLOH \\ Departement of Communication, University of Prof. Dr. Moestopo (Beragama), Jakarta, Indonesia \\ *rialdo@dsn.moestopo.ac.id
}

\begin{abstract}
In a big city like Jakarta, the community's need for public sphare as a means to carry out activities with various activities together is very important and useful. Public sphare is realized through social interactions that are accommodated in public sphares so that learning occurs between humans with one another, one community with another community, continues until finally there is a unity, understanding, together that heterogeneity in one city is a necessary necessity. must be shared and accepted. The theoretical framework used in this research is public communication and the concept of public sphare from Habermas. The purpose of this study is to analyze how the DKI Jakarta Provincial Government utilizes public sphare in this case called the Child Friendly Open Public sphare (RPTRA) as a public communication medium. This research approach is qualitative with the method used is a case study. The results of the study indicate that the existing RPTRA in various urban villages as public sphares in DKI Jakarta shows that the DKI Jakarta provincial government has optimally utilized the existence of this RPTRA as evidenced by the granting of access for residents to use it. However, public communication carried out by the provincial government has not been fully utilized. The objective condition of DKI Jakarta's public sphare is still not able to become a medium of public communication that is able to encourage egalitarian freedom of thought and action in the public sphere.
\end{abstract}

Keyword: DKI Jakarta Government, RPTRA, Public Communication

\section{BACKGROUND}

Jakarta as the State Capital requires a representative public sphare to serve as a means of carrying out activities with various activities jointly realized through social interactions that are accommodated in public sphares so that learning occurs between humans and one another, one community to another, continues. until finally there is a common understanding that heterogeneity in one city is a necessity that must be lived and accepted together.

Therefore, the public sphare becomes a space of freedom for the community to do their activities visually and physically. The public sphere appears as a specific area and part of civil society as a place for commodity exchange and social work governed by its own rules. The term public sphere originated from the opinion of Jurgen Habermas in 1962 in his writing which was later translated in 1991 entitled The Structural Transformation of The Public Sphere.

The public sphere is a space for various public discussions and debates regarding a public issue, where every individual as part of the public has an equal portion of opinion and is guaranteed his freedom from intervention and restriction from other parties so that it does not create a hegemony of opinion but fosters public opinion which is expected to help the emergence of fair public policy in (Malik, 2018).

Ideally, the public sphere has a very broad scope and is formed from the natural process of individual interaction and accumulation of public groups, therefore in public studies the definition of public is defined in general terms, State and society. Thus, the state plays a role in providing a public sphare that can become a space where members of the community as citizens have full access to all public activities, they have the right to carry out independently in it including developing public discourse such as expressing opinions orally and in writing.
Based on a formal agreement from the local government and various communities, the public sphare is transformed into a space for interaction. In this case the public sphare is seen as not formed from an activity or communication process but based on access (Brodin, 2006) (in Malik, 2018) meaning that the behavior and communication carried out by various individuals are oriented towards others through the use of various accesses for the public as subject.

There are three principles of public sphare, namely: 1) Easy access to information. Today's technology allows members of society to gain access to information. In the early days of developing public sphare, this access was only owned by a small group of people, in this case the bourgeoisie. The existence of the public sphere is then growing along with the rapid development of mass media. Mass media increasingly allows every member of the community to convey their ideas and ideas to be discussed in public forums; 2) There is no preferential treatment (privilege) to discussion participants (participants). The absence of privilege means that every member of society has equality in the speech process. No group is more dominant over another group; 3) Participants/participants provide rational reasons in discussing seeking consensus. Rational reasons are an important requirement for the realization of a good public sphare. Rationality in the debate will ensure that the debate that takes place is a debate that can be accounted for with correct and appropriate sources of information, so as to avoid the occurrence of coachman debates or emotional battles between participants. (Rouper, Toulouse, 1998 in (Salman, 2017).

In the context of Indonesia, the existence of public sphares in a certain area should be a means of communication to strengthen bonds in society. Public sphare becomes a forum for various groups so that each 
is able to interact in a positive sense. Especially for DKI Jakarta as the nation's capital. The need for public sphare in DKI Jakarta continues to increase so that the DKI Jakarta Provincial Government continues to try to increase the percentage of green open space for its citizens.

(Djamaluddin, 2018) states that in the context of the City of Jakarta, public sphare in urban areas is a space that can indirectly encourage someone to maintain and develop their own city. Jakarta is already better than other cities in terms of open public sphare. Jakarta as the capital city does not yet have sufficient public sphare, from the ideal amount of public sphare availability of around 30\% Jakarta only has about $9 \%$ availability which is designated as a place for interaction between residents and even public sphares such as sidewalks and pedestrian paths have also been converted into parking lots or place to sell.

Various efforts continue to be made by the DKI Jakarta Provincial Government to improve the quality of life of its citizens. Providing child-friendly public sphares and green open spaces are examples of efforts to achieve this. Therefore, the DKI Jakarta Provincial Government established and developed Child Friendly Integrated Public sphares (RPTRA) in various areas of the capital city.

The Child Friendly Integrated Public sphare (RPTRA) is a public sphare in the form of a child-friendly green open space equipped with various facilities that support child development, parental comfort, as well as a place to interact with all citizens from various circles. RPTRA is open to the public and built in the middle of residential areas, so that the benefits can be felt by local residents. The facilities in the RPTRA are not only childfriendly, but also disabled-friendly. In addition, RPTRA is also equipped with CCTV (closed circuit television) surveillance which makes this area have a good security system, so parents do not have to worry about the safety of their children when playing and studying.

The process of developing, supervising, and maintaining the RPTRA involves the surrounding community. As of 2018, the DKI Provincial Government has established 296 RPTRAs in each sub-district. This number has exceeded the initial target of 267. From this figure, a total of 228 RPTRA units were built with funding from the Regional Revenue and Expenditure Budget (APBD), while 68 units were built using donations from Corporate Social Responsibility (CSR) funds.

As a child-friendly space, RPTRA provides various play facilities made of special plastic and metal materials with an emphasis on safety, such as slides, swings, seesaw, and other games. In addition to playing facilities, there are also futsal and badminton courts as a children's exercise room. RPTRA is also equipped with a garden decorated with various plants and a compost center that recycles waste. With the park in the RPTRA, it is hoped that residents can enjoy the coolness of green open spaces and encourage children to care about the environment.
RPTRA not only provides a place for outdoor play, but also a library and multimedia room which is intended as a place for children to learn. What's more, RPTRA is equipped with wifi and other public facilities such as PKK Mart, lactation rooms, toilets, and multi-purpose rooms.

Certain RPTRAs even allow the holding of meetings, celebrations, recitations, and social services. In addition, in an emergency, the RPTRA can become a refugee post for residents affected by disasters, such as floods and fires. To maintain and maintain the RPTRA and all the facilities in it, the DKI Provincial Government has deployed officers for the Handling of Public Infrastructure and Facilities (PPSU). In addition, because the RPTRA is a public sphare that is the result of collaboration with the community, the residents around the RPTRA also help maintain and maintain this jointly owned facility.

RPTRA is expected to be a place for residents, especially children, to interact, thus creating a good social environment and a community with a quality of life.

Child Friendly Integrated Public sphare (RPTRA) is the concept of public sphare in the form of green open spaces or gardens equipped with various interesting games, CCTV surveillance, and rooms that serve the interests of the community around the RPTRA such as library rooms, PKK Mart, public sphares. lactation, and others.

In 2018, the DKI Jakarta Provincial Government has established as many as 290 RPTRAs in each kelurahan. This number has exceeded the set target of 267. For this reason, 2018 is the last year of RPTRA development. A total of 47 RPTRAs are planned to be built with the Regional Revenue and Expenditure Budget (APBD). As of March 2019, as many as 296 RPTRAs have been inaugurated by the DKI Jakarta Provincial Government which are spread across all sub-districts. (accessed from (statistik.jakarta.go.id, 2019).

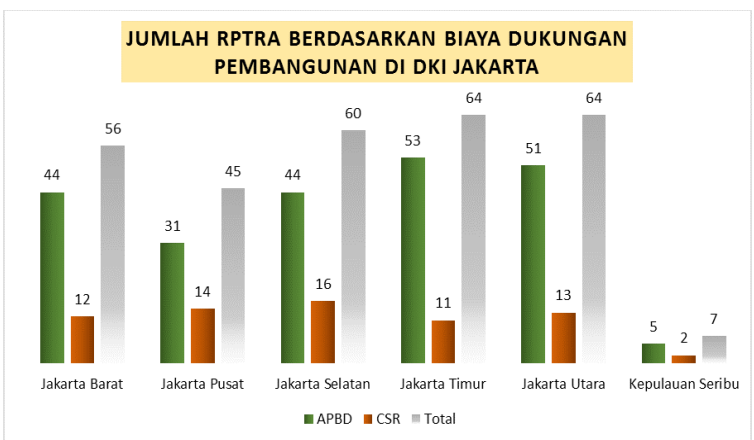

Figure 1. Number of RPTRAs in Jakarta

source: https://statistik.jakarta.go.id/, 2019

Based on data obtained from the Office of Empowerment for Child Protection and Population Control of DKI Jakarta, it can be seen that the areas with the highest number of RPTRAs are in East Jakarta Administrative City and North Jakarta Administrative City with 64 units of RPTRA. A total of 228 RPTRA units in DKI Jakarta were built with funding from the DKI Jakarta APBD and 68 RPTRA units were built with Corporate Social Responsibility (CSR) financing. 
From the above phenomena, to strengthen this research, the public communication theory is used which is defined as communication activities and strategies aimed at the targetaudience(Dijkzeul,D., \&Moke,2005). This means that public communication is a strategy that is applied by an organization in carrying out programs related to the public. In another sense, public communication is the exchange of messages with a number of people within an organization or outside the organization, face to face or through the media (Morissan, 2020). The purpose of public communication is to provide information to the target audience and to increase awareness and influence the attitudes or behavior of the target audience. In short, public communication is a strategic tool consisting of the use of various media in a comprehensive information dissemination campaign to convey a certain message to a specific audience. When compared, interpersonal communication or group communication with public communication, public communication is a type of communication that is consistent, formal, and goal-oriented.

Meanwhile, the concept of public sphare according to Habermas in (Fatah \& Fatanti, 2019) is a diversity or a very complex network. Each form of fellowship can build its own public sphere.

The role of public sphare (Carmona, et al 2008) consists of the following aspects: 1) Economics, which has a positive influence on property and encourages regional performance; 2) Health, namely encouraging people to be active in physical activity and providing informal and formal spaces for sports activities; 3) Social, namely providing space for social interaction and learning at all ages, reducing the risk of crime and anti-social attitudes, reducing the dominance of motorized vehicles so that the number of accidents can be reduced and encouraging and improving community life; 4) Environment, namely encouraging the realization of sustainable transportation, improving air quality, creating opportunities for the development of biodiversity.

Various studies that generally examine public sphares have been carried out including (Sugiyanto \& Sitohang, 2017), this study aims to determine the optimization of Green Open Space as a public sphare in Ayodia Park, South Jakarta City. In this context, the researcher utilizes the concept of optimization, green open space, and development administration. Using qualitative methods, the researcher then explored the perceptions of informants consisting of the Head of the South Jakarta City Parks and Cemetery Sub-department and the visitors to Ayodia Park. The results show that the function of the Green Open Space at the research location is not optimal because there are several factors that influence it, namely garden facilities that still need to be added and improved, in addition to the lack of variety of activities. In order for the Green Open Space to become a forum for social interaction for residents who can create creativity and motor activities for visitors, periodic and sustainable socialization is needed $\backslash$
The difference with the current research lies in the objectives studied, previous research focused on optimizing green open space as a public sphare with an optimization concept, while the current research is more on public sphare as a medium of public communication. The similarities of the two studies on the object under study are public sphares managed by local governments

Furthermore (Rangkuti \& Maksum, 2019) stated that the research was to explain the implementation of the Child Friendly School Policy set by the Ministry of Women's Empowerment and Child Protection and analyze the supporting and inhibiting factors for the implementation of the Child Friendly School Policy in Depok City. This study uses a qualitative method which shows that the implementation of the Child Friendly School Policy at SMP Negeri 6 Depok has been going well, assessed in the context of the process, results (output), impact (outcome) and causal connection. The factors that support the implementation of the Child Friendly School Policy in Depok City are good and smooth communication, the attitude and commitment of all school residents, coordination between the Depok Regional Government and the School and the positive support of all school residents, parents, and the surrounding community. However, there are still inhibiting factors, namely the limited school budget and the number of teachers and the density of teacher activities causing the implementation of policies to be not optimal. To expedite the implementation of child-friendly school policies, collaboration between all parties, both central and local governments, schools and communities is needed

The difference with the current research lies in the objectives studied, previous research describes the implementation of the Child Friendly School Policy set by the Ministry of Women's Empowerment and Child Protection and analyzes the supporting and inhibiting factors for the implementation of the Child Friendly School Policy in Depok City. Meanwhile, the current research aims to analyze the open public sphare as a medium of public communication between the local government, in this case the DKI Jakarta Provincial Government and the community.

In the context of this research, what is known as public sphare is an open space for children. From this background, this study aims to analyze how public sphare is a medium of public communication in DKI Jakarta with the community through the establishment of Child Friendly Integrated Public sphares (RPTRA).

\section{RESEARCH METHODS}

This research uses constructivism paradigm. Researchers use this paradigm because it is oriented to find understanding or meaning for a thing and provide an explanation using their own reasoning, in this case is how the public sphare as a medium of public communication. The flow of constructivism states that reality exists in 
various forms of mental construction that is based on social experience, is local and specific, and depends on the party doing it. Therefore, a reality observed by researchers cannot be generalized to everyone. In the paradigm, the relationship between the observer and the object is a unity, subjective and is the result of a combination of interactions between the two. The researcher underlies the research using this paradigm with the aim of revealing the activities comprehensively and in depth. The research approach uses qualitative research. Qualitative research is a research method used to examine the condition of natural objects, where the researcher is the key instrument, the data collection technique is done by triangulation (combined), the data analysis is inductive, and the results of qualitative research emphasize meaning rather than generalization (Sugiyono, 2016 ).

In this study, the researcher uses a qualitative descriptive approach which aims to identify, obtain, and provide an overview or paradigm of a symptom. This study seeks to show an overview of the DKI Jakarta provincial government's public communication media through the public sphare, namely the Children's Open Public sphare (RPTRA) which is expected to be able to produce an in-depth description of speech, writing, and observable behavior from an individual, group., society, a particular organization in a particular setting context which is studied from a complete and comprehensive point of view.

The method used is a qualitative approach. This research method uses case studies. A case study is a comprehensive description and explanation of various aspects of an individual, a group, an organization (community), a program or a social situation. Case study researchers seek to examine as much data as possible about the subject under study (Mulyana, 2018). The technique of collecting data is through searching various sources and literature, both from government documents as well as print and electronic mass media reports, journals and books related to public administration and communication and interviews. The primary and secondary data are processed and described in narrative form according to the data needs. Furthermore, the data analysis process is carried out based on the theories and concepts of policy and public communication and then the data interpretation process is carried out.

\section{RESULTS AND DISCUSSION}

The presence of public sphare as a fulfillment of public facilities, cannot be separated from the active role of the community so that these public facilities can function optimally. In an effort to introduce and invite the public to use public sphare in a positive way, the DKI Jakarta Provincial Parks and Cemetery Service has carried out socialization by making direct invitations to people living around and outside the park to use the park as a public sphare.

In this regard, since 2015 the DKI Jakarta Provincial Parks and Cemetery Service has implemented a program called "Come to the Park" to introduce Child Friendly Open Public sphares (RPTRA). This program is referred to as a form of introduction and at the same time an invitation to the community to use city parks as public sphares. This program emerged against the background of the lack of public interest in using city parks as public sphares and it is alleged that most DKI Jakarta Provincial Government residents tend to prefer to spend their free time in shopping centers or other hangout spots rather than in city parks so that the existence and function of city parks neglected public sphare.

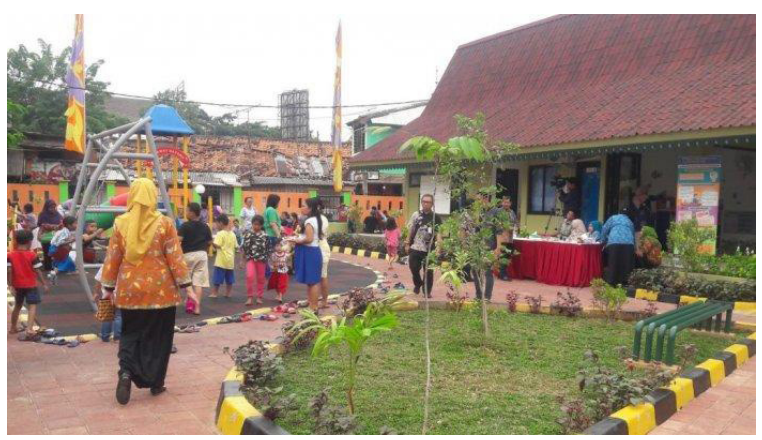

\section{Figure 1. One of the RPTRA in Jakarta}

source: jakarta.go.id

Routine programs in collaboration with nongovernmental organizations and communities are expected to be able to encourage people's motivation to take advantage of city parks in a positive way, especially if they are willing to be actively involved in their maintenance, as expected by the DKI Jakarta Provincial Government. That with the "Come to the Park" program, the community works hand in hand to build a healthy garden. The park belongs to all of us, meaning that it is obligatory for us to maintain its beauty, sustainability and security. Through this invitation, it turned out that the community was enthusiastic and welcomed the "Come to the Park" program as expressed by visitors who stated that they were happy with the efforts of the DKI Jakarta Provincial Government to invite residents to maximize the park as a space for residents' interaction. And this kind of program is a progress, considering that in previous years the government only built parks without "inviting and enlivening" the function of parks as public sphares.

Given the enthusiastic public response to the Come to the Park program, the DKI Jakarta Provincial Parks and Cemetery Service is eager to continue the program until all sub-districts and even urban villages have an RPTRA.

Public sphere means social life in which public opinion can be formed. According to (Djamaluddin, 2018), access to public sphares is in principle open to all citizens, citizens act as public when they deal with matters relating to the public interest without being coerced. The public sphere is a sphere of influence that is created when individuals involve others in communicating, through conversations, arguments, debates, or questions about subjects of common concern or topics that affect the wider community. According to (Cox, 2010), public sphare is 
not just words; but includes visual and nonverbal symbolic actions; such as banners, photography, films and others. In this study, the discussion is limited to conversation, argument and nonverbal communication, not including communication media such as banners, photography or films. Public sphare is a bridge of interaction between rulers and society.

The power to achieve legitimacy and community experience and understand the direction the community wants through dialogue in the public sphere, while the community can voice their interests so that the government can accommodate them. Only through this public sphare can a mature society be realized and free from oppression and overcome the crisis they face.

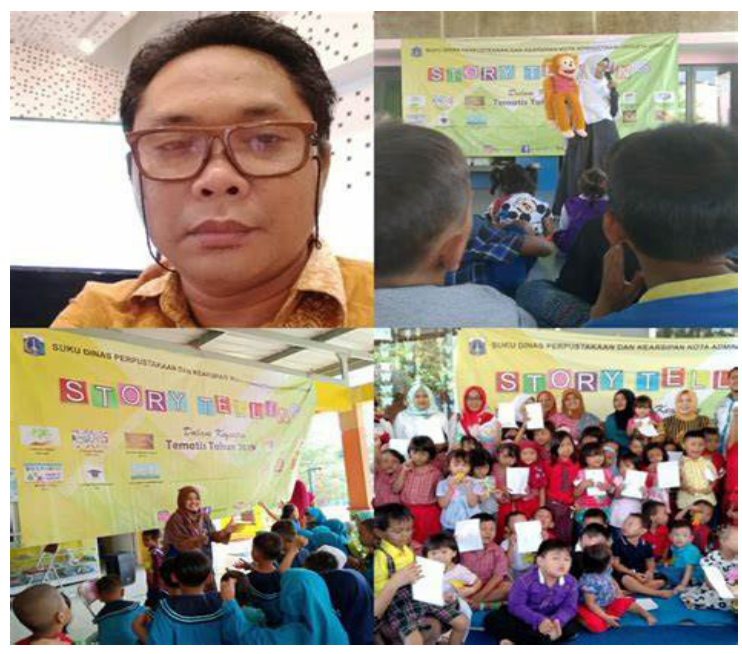

Figure 2. RPTRA as a Means of Socialization and Learning implemented by North Jakarta Sub-dept. Pursip

source: jaranan.org.id

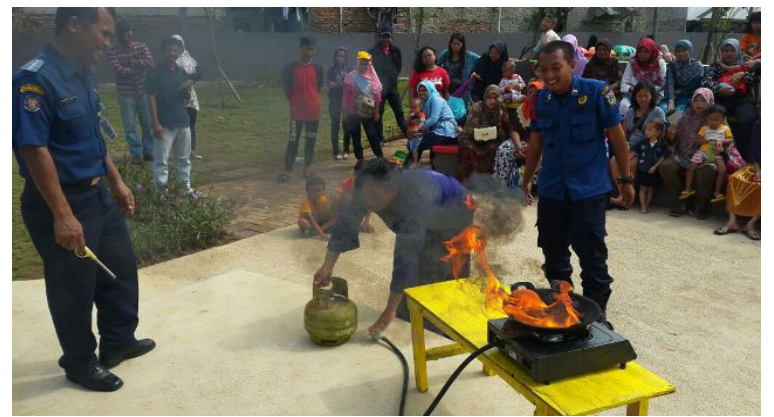

Figure 3. Socialization for Residents at RPTRA from the DKI Jakarta Fire Department

source: jakarta.go.id

Public sphare according to Habermas (Hardiman, 2009) is a diversity or something very complex. Each form of network can build its own public sphare. That the public sphare is just a 'physical place', but the communication of the citizens themselves which only produces space between In the area of TNKpS there is a public sphare from fishermen's associations as well as those provided by the government. Physical public sphare in the Thousand Islands Regency provided by the government is the RPTRA (Child Friendly Integrated Public sphare) which is located opposite the district office next to the pier, play facilities for children are provided, RPTRA is also a place for several agencies to socialize their program, such as from the Ministry of Agriculture regarding the use of fruit peels as fertilizer, counseling on waste banks from the LHK (Environment and Hygiene) Sub-Department, used to conduct Musrembang (Development Planning Deliberations) which was attended by the Governor of DKI. The public sphare that has been using fishermen for years has become a gathering place for fishermen and is known as the place to hang out at the Pier, fishermen regularly hang out on Friday mornings.

In addition to physical development, RPTRA indirectly also builds hope because it has the potential to play a role as a melting pot of residents with various heterogeneous backgrounds and become a catalyst for various community activities, ranging from social, cultural and even family recreation activities. Public sphare accommodates social interaction. If this takes place in a sustainable manner, it can encourage learning for the community to understand each other, share space between different communities, and ultimately build a unified understanding of diversity as something that is necessary.

A different concept offered in the RPTPA is that the land that is built is not just a park. RPTPA is encouraged to be able to meet the 31 indicators of child-friendly cities set by the Ministry of Women and Children Empowerment (Kemen PPA). Another interesting thing is that the RPTRA was built close to residential areas, especially the poor. So that RPTRA can act as a community center for the surrounding community (Djamaludin, 2018).

As a community center, RPTPA is aspired to have multifunctions that can accommodate community activities and voices, ranging from activities such as sports, maternal and child health activities, to even political education infrastructure. In addition, there is also a library, a place to play futsal, a jogging track, and an amphi theater. These facilities are to support the activities of children and youth in a positive way.

The functions of the RPTRA are in accordance with the Regulation of the Governor of the Province of the Special Capital Region of Jakarta Number 196 of 2015, article 6 as follows: 1) Public open parks, 2) Playgrounds and children's growth and development, 3) Infrastructure and partnership facilities between the Regional Government and the community in fulfilling children's rights, 4) part of the infrastructure and facilities of a child-friendly city, 5) green open spaces and groundwater absorption areas, 6) infrastructure and facilities for social activities of citizens, including the development of knowledge and skills of PKK cadres, 7) efforts to increase family income, 8 ) Family information and consultation center, 9) Beautiful and comfortable family yard, and 10) Management information system.

RPTRA is part of the urban design perspective. As a public sphare, the RPTRA will be the main focus in the process and product in the perspective of urban design. Sunaryo et al., (2010) explain the characteristics of public 
sphare itself, namely: First, public sphare is a place where people interact, carry out various activities in a shared and shared manner, including social, economic and cultural interactions, with the main emphasis on social activities. Second, public sphare is held, managed and controlled jointly, either by the state or privately, which is dedicated to the public interest.

This becomes relevant to the study in this study, considering that the RPTRA that was built was the result of cooperation between the state and the market through CSR. Public sphare certainly does not run in a vacuum, there will be changes that will affect the ownership status of public sphare. However, in the context of this change, an overview can still be drawn that a space dedicated to the public interest can be defined as a public sphare. So in this context, RPTRA is a public sphare. Consensus becomes the controlling aspect, not a certain individual or group, either the tyranny of the majority or the domination of the minority. Third, public sphare is a space that is open and accessible visually and physically for all without exception. A public sphare should be open to everyone from any background without exception. In this case the public sphare, its existence is like public goods whose utilization and use cannot deny other parties. Finally, the fourth characteristic is that public sphare is a space where people get freedom of activity. The spirit that surrounds the public sphere is freedom of expression and self-actualization, but because of the public's characteristics, this freedom is not absolute, there are always limits to other freedoms.

The RPTRA development project can be an important element in advancing the civilization of a city like DKI Jakarta. Because from this space, social cohesion and social capital between residents can potentially be strengthened by the accumulation of interactions. The hope is that the dispersed people will stick together to become civil society. However, as Foucault has warned, space will always focus on the most basic of the practice of power. Likewise, what was conveyed by Henri Levebre that space is a dynamic social product and is shaped by people who have control and of course domination over power.

The classic problem related to public sphare in Indonesia, especially DKI Jakarta is the public sphare which is often controlled by certain parties. Public sphare is even contested and often commercialized. Pedestrians in big cities are being taken over by big property companies. From this case by case case, it is not surprising that citizens cannot understand and appreciate the essence and importance of a public sphare.

\section{CONCLUSION}

Public sphare is dedicated to public needs and becomes a meeting place for various public interests. Social, economic and political interactions that are built in the public sphere require the meaning and function of access, involvement and socialization. Public sphare management (RPTRA) in DKI Jakarta is still not fully used by the public for interaction. On the other hand, the DKI Jakarta Provincial Government has optimally utilized the existence of this RPTRA, as evidenced by the provision of access for residents to use it, the presence of staff assigned to maintain it and various supporting facilities. However, public communication carried out by the provincial government has not been fully utilized. Only certain times the existence of RPTRA is used. Of course, this is a challenge for stakeholders in DKI Jakarta's policy and public communication, from the governor to the lurah level in formulating the ideal public sphare management. The objective condition of DKI Jakarta's public sphare is still not able to become a medium of public communication that is able to encourage egalitarian freedom of thought and action in the public sphere.

\section{REFERENCES}

Carmona, et al. (2008). Public space: The Management Dimension. Routledge, Taylor \& Francis Group.

Cox, R. (2010). Environmental Communication and the Public Sphere. SAGE Publications Inc.

Dijkzeul, D., \& Moke, M. (2005). Public Communication Strategies of International Humanitarian Organizations. International Review of the Red Cross, 87(860), 673-691. https://doi.org/https://doi.org/10.1017/ S1816383100184504

Djamaluddin, N. (2018). RPTRA Jakarta Harus Menjadi Model Bagi Kota Lain di Indoesia.

Fatah, Z., \& Fatanti, M. N. (2019). Mempolitisasi Ruang Virtual: Posisi Warga-Net dalam Praktik Demokrasi Digital di Indonesia. Jurnal Ilmiah Manajemen Publik Dan Kebijakan Sosial, 3(1), 306. https://doi. org/10.25139/jmnegara.v3i1.1459

Malik, A. (2018). Ruang Publik sebagai Representasi Kebijakan dan Medium Komunikasi Publik. Sawala: Jurnal Administrasi Negara, 6(2), 82-88. https://doi.org/10.30656/sawala.v6i2.914

Morissan. (2020). Komunikasi Organisasi (Pertama). Prenadamedia Group.

Mulyana, D. (2018). Metode Penelitian Kualitatif: Paradigma Baru Ilmu Komunikasi Dan Ilmu Sosial Lainnya (Kedelapan). PT. Remaja Rosdakarya.

Rangkuti, S. R., \& Maksum, I. R. (2019). Implementasi Kebijakan Sekolah Ramah Anak Dalam Mewujudkan Kota Layak Anak di Kota Depok. Publik (Jurnal Ilmu Administrasi), 8(1), 38. https:// doi.org/10.31314/pjia.8.1.38-52.2019

Salman. (2017). Media Sosial Sebagai Ruang Publik. Kalbis Socio: Jurnal Komunikasi Dan Bisnis, 4(2), 124-131.

Statistik, J. go. i. (2019). RPTRA Jakarta Harus Menjadi Model Bagi Kota Lain di Indonesia. https://statistik. jakarta.go.id/jumlah-ruang-publik-terpadu-ramah- 
anak-rptra-yang-diresmikan-pemprov-dki-jakartahingga-tahun-2019/

Sugiyanto, E., \& Sitohang, C. A. V. (2017). Optimalisasi Fungsi Ruang Terbuka Hijau Sebagai Ruang Publik Di Taman Ayodia Kota Jakarta Selatan. Jurnal Populis, 2(3), 205-218.

Sugiyono. (2016). Memahami Penelitian Kualitatif. Bandung: Alfabeta. https://doi.org/10.1111/j.13652036.2009.03946.x
Republik Indonesia. (2007). Peraturan Menteri Dalam Negeri No 1 Tahun 2007 tentang Penataan Ruang Terbuka Hijau Kawasan Perkotaan. Lembaran Negara RI Tahun 2007. Jakarta: Sekretariat Negara.

Republik Indonesia. (2012). Peraturan Daerah No 1 tahun 2012 tentang Rencana Tata Ruang Wilayah. Lembaran Negara RI T.

Peraturan Gubernur Provinsi Daerah Khusus Ibukota Jakarta Nomor 196 Tahun 2015 